\title{
Sport Hunting to Save Nature? The Case of Uganda
}

\author{
Amos Ochienga," ${ }^{\mathrm{a}}$ Ingrid J. Visseren-Hamakers ${ }^{\mathrm{b}}$, René Van Der Duim ${ }^{\mathrm{c}}$

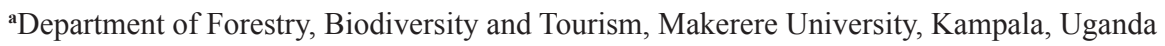 \\ bDepartment of Environmental Governance and Politics, Radboud University, Nijmegen, The Netherlands \\ ${ }^{\mathrm{c} C u l t u r a l ~ G e o g r a p h y ~ G r o u p, ~ W a g e n i n g e n ~ U n i v e r s i t y ~ a n d ~ R e s e a r c h, ~ W a g e n i n g e n, ~ T h e ~ N e t h e r l a n d s ~}$
}

\#Corresponding author. E-mail: aochiengd@gmail.com

\begin{abstract}
After having banned sport hunting in 1979, Uganda reintroduced it in 2001 around Lake Mburo National Park, and in 2006 in the Kabwoya and Kaiso-Tonya Game Management Area, with the aim to reduce human-wildlife conflicts, especially poaching, by providing incentives for the local inhabitants in order to positively change residents' attitudes towards wildlife. We conducted interviews and reviewed documents to analyse and evaluate the impacts of reintroduction of sport hunting. The income generated from sport hunting was used to provide social services and implement social development projects. There was no proof of hunting income being used for conservation purposes. Although the local perceptions of the sport hunting benefits varied, the benefits did initially help to improve local residents' attitudes towards wildlife and poaching temporarily stopped — but resumed later. Hence, this study shows that the common underlying assumption of sport hunting policies and other market- and community-based approaches to conservation - that when local residents receive benefits, they will appreciate wildlife—is debatable.
\end{abstract}

Keywords: effectiveness, livelihoods, poaching, sport hunting, Uganda

\section{INTRODUCTION}

Hunting as a sport in Africa dates back to the 1800 s, following the arrival of early explorer-hunters on the continent (Ochieng 2019). In Uganda, the colonial administration demarcated areas abundant with wildlife for protection, hunting, and centralised control over wildlife by the 1926 game ordinance, which also limited all forms of hunting. Sport hunting (also known as 'trophy' or 'safari' hunting) is an activity where a tourist pays to hunt and kill an animal with desired physical attributes, such as large horns, tusks or a certain body size (Lindsey et al. 2007; Booth 2017). Although

\begin{tabular}{|l|l|}
\hline \multicolumn{2}{|c|}{ Access this article online } \\
\hline Quick Response Code: & Website: \\
\hline & www.conservationandsociety.org \\
\cline { 2 - 2 } & \\
\hline & \\
\end{tabular}

sport hunting has many forms (Lindsey et al. 2016), we particularly refer to trophy hunting (found in Uganda): hunting particular animals to keep the animal or certain body parts (e.g., entire head or hides, but this may also include scrotum, tail, hooves, or teeth) as souvenirs or mementos (trophies). It is implemented following market-based (McAfee 1999) and community-based (Hulme and Murphree 2001) conservation policies.

Sport hunting - especially in Africa-has attracted mixed reactions. Several countries in Southern Africa continue to practice it, including Zimbabwe and South Africa (Booth 2017). After having it banned in 1979, Uganda reintroduced it in 2001. Kenya (although still maintaining hunting for birds) and Botswana (although now reintroducing it again), banned sport hunting and are promoting photography tourism as a source of income for local communities (Muposhi et al. 2016).

Currently, sport hunting advocates (e.g., Yasuda 2011; Booth 2017) argue that local communities around protected areas are willing and able to sustainably manage and use wildlife, especially when they share in the income and meat from legally hunted animals (Muposhi et al. 2016). They say

Copyright: (C) Ochieng et al. 2020. This is an open access article distributed under the terms of the Creative Commons Attribution License, which permits unrestricted use and distribution of the article, provided the original work is cited. Published by Wolters Kluwer - Medknow, Mumbai | Managed and supported by the Ashoka Trust for Research in Ecology and the Environment (ATREE), Bangalore. For reprints contact: reprints@medknow.com 
that hunting operators can promote anti-poaching campaigns by integrating (former) poachers in conservation programmes as village scouts (Lindsey et al. 2007). Recent studies (e.g., Di Minin et al. 2016 and Muposhi et al. 2016) show that Zimbabwe's trophy hunting industry generates approximately USD 16 million/year. The authors highlight the potential of sport hunting for African governments to involve and motivate local residents when political and governance structures are adequate. This links to broader conservation and development debates, in which, it is also argued that an effective conservation policy should be able to bring financial outcomes to create positive local attitudes towards wildlife. As such, communitybased conservation policies (CBCs) were introduced to allow local people to participate in the governance of protected lands by involving them in land-use policy and management decisions (Hulme and Murphree 2001) as well as granting people ownership rights over wildlife and giving local people economic benefits from wildlife conservation (Hackel 1999). Because wildlife lives on both government and private land, private landowners become critical stakeholders to be involved in policy and management decision making as well as in the sharing of wildlife-related benefits.

However, Bekoff (2013) proposes a paradigm shift from a dominant and exploitative conservation to a compassionate one. Especially following the incident in July 2015, when a sport hunter killed a radio-collared lion named Cecil in Zimbabwe, the anti-hunting movement intensified its campaigns against killing of animals (Lindsey et al. 2016), or linking sport hunting to conservation. These campaigns-so far-only had a limited impact in terms of policy changes (Carpenter and Konisky 2017). Related, the African Union has adopted an animal welfare strategy recognising animals as sentient beings, including wild animals, farm animals, and animals used in research (AU 2017).

This paper contributes to these discussions on the use of sport hunting to address conservation-development challenges by analysing and evaluating the impacts of sport hunting in Uganda, around Lake Mburo National Park (hereafter Lake Mburo), where it was first piloted in 2001, and the Kabwoya and Kaiso-Tonya Game Management Area (hereafter Kabwoya) to which it was extended in 2006 (Figure 1). The government reintroduced it in order to address poaching, which was affecting the survival of species in the two areas: lions became extinct in Lake Mburo and rhinoceros in the whole country, and other species (currently listed for sport hunting; Table 1) equally declined (UWA 2015). The basic idea behind the reintroduction was to generate and share benefits as buyin for local residents to support and participate in wildlife conservation and stop poaching. Private hunting companies are supposed to generate these benefits. In Uganda, these benefits are usually shared following the established benefitsharing rules that specify who the beneficiaries are, as well as how many benefits they are supposed to receive. These rules vary from one sport hunting arrangement to another. There are currently 12 sport hunting arrangements in Uganda, along with Lake Mburo and Kabwoya.
Lake Mburo is found in the southern savannah rangeland in the district of Kirihura, Uganda. It is the smallest savannah park in the wildlife migratory corridor connecting Northern Tanzania to Southern Sudan. The park is neighboured by the Bahima (nomadic pastoralists and subsistence farmers) and a few other tribes, such as the Bakiga and Baganda (cf. Ochieng 2019). Located in Hoima district, Kabwoya is part of the great Albertine Rift: the western branch of the East African Rift that runs through western Uganda and through parts of the Democratic Republic of the Congo (DRC), Rwanda, Burundi, and Tanzania. Kabwoya covers a total area of 194 sq. km (Plumptre et al. 2009). The district local government development plan 2015/2016-2019/2020 estimated the district population to be at 573,903 people in 2014 , with an annual growth rate of $4.2 \%$ with over $90 \%$ living in rural areas (HDLG 2015). The major economic activities by the local residents include subsistence farming, pastoralism, fishing and small-scale trade.

Uganda reintroduced sport hunting to achieve the following objectives: (1) reduce human-wildlife conflicts - especially poaching by the local residents; by (2) positively changing residents' attitudes towards wildlife; through (3) providing incentives for the local inhabitants (UWA 2001). In this paper we evaluate and analyse the impacts of the sport hunting policy in Uganda. We use the term 'impact' to refer to the contributions of the sport hunting policy to achieving these formal policy goals.

\section{CONCEPTUAL FRAMEWORK}

In this paper, we adopt the concept of effectiveness (Levy and Young 1994) to evaluate and analyse the impacts of Uganda's sport hunting policy. Levy and Young (1994: 20) define effectiveness as 'the extent to which a regime ameliorates the problem(s) that prompted its creation.' Thus, we analyse effectiveness by evaluating if and to what extent the three goals of sport hunting policy have been achieved. We do so by answering the following research question: what are the impacts of the sport hunting policy around Lake Mburo and Kabwoya in terms of reducing poaching, improving wellbeing, and changing residents' attitudes towards wildlife?

The concept of effectiveness has been defined, discussed, and operationalised in literature on regimes, and in particular, international environmental regimes (Mitchell 2003), institutions (Giddens 1984), and policy evaluation (Crabbé and Leroy 2008; Visseren-Hamakers 2018).

Policy evaluation literature is inspired by several traditions, namely rational-instrumental ex-post and ex-ante evaluation (Arts and Leroy 2006) and interpretative policy analysis (Hajer and Wagenaar 2003). Whereas the evaluator in the former determines policy (in)effectiveness based on particular policy goals (Arts and Leroy 2006), the evaluator in the latter considers policy (in)effectiveness as a matter of multiple interpretations - based on the evaluator's theoretical lens (Mosse 2005). We will include both, rational and interpretative, perspectives in our analysis. 
342 / Ochieng et al.

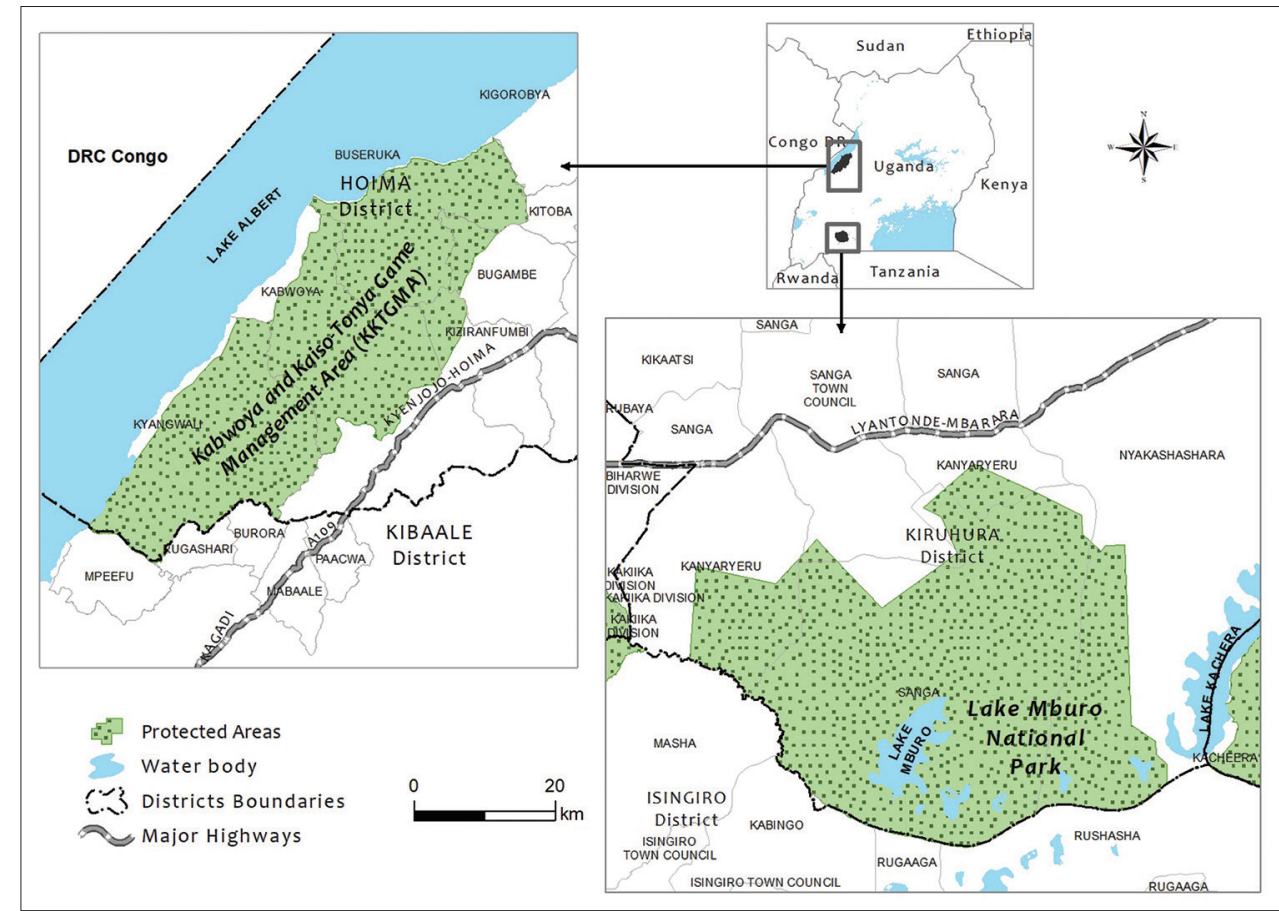

Figure 1

Location of the study areas

Source: Ochieng 2019

We thus study the effectiveness of the sport hunting policy from the perspective of whether or not the policy reaches its intended goals. In doing so, we mainly focus on the direct economic benefits from sport hunting and how they translated into social and the ecological effects. Specifically, we evaluate and analyse the perceptions of the stakeholders regarding the benefits that they receive following the implementation of sport hunting. Epistemologically, we consider both the objectivist and subjectivist approaches (Moon and Blackman 2014) towards the evaluation of these impacts. Thus, we analyse sport hunting effects based on the existing official hunting data, and through the local residents' perceptions of the benefits, collected through interviews. Since there is no such a thing as a homogeneous community (Agarwal and Gibson 1999), we expect that there may also be no homogenous view about sport hunting benefits. While some stakeholders may think that, for example, the benefits of the arrangements are insignificant, others may think the benefits are actually significant, while they are both reflecting on the same benefits generated by the policy. This is because different stakeholders usually have different interests, opinions and expectations concerning any policy implementation (Visseren-Hamakers 2018). Moreover, there may be power dynamics that make certain stakeholders benefit more than others, thereby also skewing the actual benefits towards certain stakeholders.

Since the hunting policy lacks clear criteria or indicators for assessing its effectiveness, we adopt the three formal policy goals and categorise the direct impacts into four categories: 1) the number of animals hunted through sport hunting; 2) poaching as a form of human-wildlife conflict; 3 ) impacts on wellbeing; and 4) changed resident's attitudes (Table 1). We briefly highlight these four categories and selected criteria below:

\section{The number of hunted animals}

We analyse the data on numbers of animals hunted through sport hunting between 2001 and 2016 around Lake Mburo and 2006-2016 in Kabwoya. Further, we analyse the hunting agreements signed by the actors, including rule implementation and adherence in the two areas.

\section{Human-wildlife conflicts and poaching}

Human-wildlife conflicts (HWC) refer to "conflicts which occur whenever an action by humans or wildlife has an adverse impact upon the other" (Conover 2002:8). In this paper, we focus on poaching by the local residents as a form of humanwildlife conflicts, since this is what the Ugandan government meant by HWC in its sport hunting policy. Uganda responded to declining wildlife populations in the 1970s due to poaching by a ministerial decree that banned all forms of hunting (Ochieng 2019). Although the local residents usually hunt for subsistence, in some instances, they practice poaching as a form of revenge - especially where wildlife destroys crops or kills humans (Ochieng 2019). We therefore operationalise conservation impacts in terms of reducing poaching and analyse the rate of poaching based on the available seizure data to determine whether there is a decrease or increase in poaching in the two areas. We also analyse the perceptions of 
Table 1

Indicators for assessing the impacts of sport hunting policy in Uganda

\begin{tabular}{|c|c|c|c|c|}
\hline Policy goal & Aspects & Indicators & Data & Research methods \\
\hline \multirow{5}{*}{$\begin{array}{l}\text { Reducing } \\
\text { human-wildlife } \\
\text { conflict (poaching) }\end{array}$} & \multirow{2}{*}{$\begin{array}{l}\text { Hunted } \\
\text { animals } \\
\text { through } \\
\text { sport }\end{array}$} & $\begin{array}{l}\text { Number of animals hunted per year through sport } \\
\text { hunting }\end{array}$ & $\begin{array}{l}\text { Hunting evaluation } \\
\text { report(s) }\end{array}$ & \multirow[t]{4}{*}{ Document review } \\
\hline & & Poaching rates per year & $\begin{array}{l}\text { Government records } \\
\text { Poaching statistics }\end{array}$ & \\
\hline & \multirow{2}{*}{$\begin{array}{l}\text { Illegal } \\
\text { hunting }\end{array}$} & Number of individuals/communities protecting wildlife & Association records & \\
\hline & & Adherence to set quota & $\begin{array}{l}\text { Animal census data } \\
\text { Sport hunting documents }\end{array}$ & \\
\hline & & Actors' perceptions regarding sport hunting & $\begin{array}{l}\text { Interview data on } \\
\text { perceptions }\end{array}$ & $\begin{array}{l}\text { Interviews and } \\
\text { informal conversations }\end{array}$ \\
\hline \multirow{5}{*}{$\begin{array}{l}\text { Provide incentives } \\
\text { for local inhabitants } \\
\text { to manage and } \\
\text { protect wildlife and } \\
\text { improve livelihoods }\end{array}$} & \multirow{5}{*}{$\begin{array}{l}\text { Financial } \\
\text { incentives }\end{array}$} & The accumulated and distributed income & Official revenue records & Document review \\
\hline & & Adherence to the revenue-sharing rules & \multirow{3}{*}{$\begin{array}{l}\text { Record of financed } \\
\text { projects } \\
\text { Association records }\end{array}$} & Interviews \\
\hline & & The projects financed by hunting income & & \multirow{3}{*}{$\begin{array}{l}\text { Informal conversations } \\
\text { and observation notes }\end{array}$} \\
\hline & & Number of directly benefitted landowners & & \\
\hline & & Actors' perceptions regarding incentives & $\begin{array}{l}\text { Interview data on } \\
\text { perceptions }\end{array}$ & \\
\hline \multirow{6}{*}{$\begin{array}{l}\text { Positively change } \\
\text { residents' attitudes } \\
\text { towards wildlife }\end{array}$} & \multirow{6}{*}{$\begin{array}{l}\text { Changed } \\
\text { community } \\
\text { attitudes }\end{array}$} & Number of residents protecting wildlife & Minutes of meetings & $\begin{array}{l}\text { Studying minutes of } \\
\text { the meeting }\end{array}$ \\
\hline & & $\begin{array}{l}\text { Number of residents allowing wild animals to freely } \\
\text { gaze on their farms }\end{array}$ & $\begin{array}{l}\text { Hunting agreements and } \\
\text { other hunting policies }\end{array}$ & Document review \\
\hline & & Number of residents reporting poachers & Association records & $\begin{array}{l}\text { Review of association } \\
\text { records }\end{array}$ \\
\hline & & $\begin{array}{l}\text { Number of residents forming associations to protect } \\
\text { and benefit from wildlife }\end{array}$ & \multirow[t]{3}{*}{$\begin{array}{l}\text { Interview data on } \\
\text { perceptions }\end{array}$} & \multirow[t]{3}{*}{$\begin{array}{l}\text { Interview and informal } \\
\text { conversations }\end{array}$} \\
\hline & & $\begin{array}{l}\text { Number of residents working with other individuals/ } \\
\text { organisations to support and benefit from sport hunting }\end{array}$ & & \\
\hline & & Residents' attitudes towards sport hunting benefits & & \\
\hline
\end{tabular}

the stakeholders on poaching, and the extent to which they are protecting wildlife in the two areas.

\section{Impacts on wellbeing}

Analyses of wellbeing normally involve a holistic perspective on how people's lives improve following the introduction of certain social and development policies (White 2008). The concept of wellbeing is related to other frameworks, such as sustainable livelihoods (Scoones 2009), but with a central focus on the individual person as well as his/her priorities and perspectives in life (White 2008). Wellbeing analyses are not only directed at "the external 'objective' measure of welfare but also people's perception and experiences in life" (White 2008: 3). Generally, wellbeing has three dimensions: 1) material (which concern the practical welfare and standard of living); 2) subjective (which concern peoples' values, perceptions and experiences); and 3) relational (which concerns personal and social relations) (White 2008:7). Although our analysis focuses on benefit sharing, as the Ugandan government uses it in the hope to reduce $\mathrm{HWC}$, we also analyse how these benefits translate into improved wellbeing for the local residents. Benefit sharing is about giving a portion of the derived advantages/profits (cf. Ahebwa et al. 2012) to help improve the wellbeing of the rural residents. In the context of this paper, we analyse improvement in wellbeing by predominantly focusing on the income and the social projects supported through sport hunting. First, we examine how, and how much of, the income was shared among the beneficiaries, and analyse actors' adherence to the revenue-sharing rules. We then show how the individual(s) and the communities utilised the hunting income for improved local wellbeing. Finally, we incorporate the residents' perceptions of these projects and whether or not these improved their wellbeing over the years.

\section{Changing local attitudes}

Through the sport hunting policy, the Ugandan government hopes to address negative attitudes of the local residents towards wildlife by sharing benefits. The idea to share benefits originated from the need to exercise justice in the use of genetic resources (Byström et al. 1999; see Archabald and Naughton-Treves 2001; Ahebwa et al.2012)_especially where these resources originally belong to a group of people whose rights to use have now been infringed. Although the term benefits has multiple interpretations (Schroeder 2007), in this study we consider benefits as the direct tangible outcomes that accrue to humans from - in our casesport hunting. They include both, monetary and non-monetary, outcomes e.g., money, physical structures built using profits from sport hunting, meat from killed animals and more.

The Ugandan government has not specified what they mean by 'changing attitudes,' let alone developed criteria to measure it. In social behaviour studies, the term attitude means a behavioural pattern or a conditioned response to social stimuli (LaPiere 1934), and normally has four components: 1) affective, 2) cognitive, 3) conative, and 4) evaluative responses to - in this case - sport hunting. We analyse residents' attitudes by focusing on specific actions and reactions by the local residents that 
adversely affect wildlife population such as poaching, as well as those actions and reactions that favour wildlife survival such as reporting poachers or allowing wildlife to freely graze on their farmland (contrary to the concept of perceptions, which we use in the subjectivist aspects of the evaluation as introduced earlier, which is broader than residents' attitudes towards wildlife).

\section{MATERIALS AND METHODS}

Two case studies were analysed (Yin 2003): Lake Mburo and Kabwoya. These case studies were chosen because: 1) sport hunting was first reintroduced around Lake Mburo in 2001 and later extended to Kabwoya in 2006, guided by the same formal goals; 2) they have both experienced humanwildlife conflicts; 3) they represent well established sport hunting policy arrangements that are based on market- and community-based conservation approaches. By analysing these, cases we were able to gain understanding of how and the extent to which they have achieved the goals of reintroducing sport hunting in Uganda. Fieldwork was conducted in four phases: February 2014-August 2014, January 2015-May 2015, October 2016-November 2016, and June 2017-September 2017. For Lake Mburo, fieldwork covered four sub-counties: Kanyaryeru, Nyakashashara, Sanga, and Sanga Town Board (Kiruhura district), and for Kabwoya three sub-counties: Kabwoya, Buseruka, Kyangwali (Hoima district).

Qualitative in-depth interviews were conducted with a total of 47 key informants who are directly involved and benefit from sport hunting: 22 ( $R=$ respondents, $\mathrm{R} 1-\mathrm{R} 22$ ) around Lake Mburo, 18 (R28-R45) in Kabwoya, and 7 (R23-27, R46-R47) that are relevant to both the areas. In-depth individual interviews with a small number of respondents enabled us to explore their perspectives on the research phenomenon (Boyce 2006). We stopped at 47 , especially when we realised that we had reached a saturation point - there were no new ideas being shared by respondents during interviews. The first author interviewed representatives from one conservation organisation (R26), two sport hunting companies (R1, R44), two tourism associations (R24, R27), four district local leaders (R32, R39-R40, R42), six government representatives (Lake Mburo, Kabwoya) (R23, R25, R31, R41, R45, R46), one wildlife expert (R47), and 31 village leaders/ local communities/ landowners (R2-R22, R28-R30, R33-R38, R43). Six respondents were interviewed twice. Most interviewees were selected using snowball sampling. NGO representatives and government officials were purposively selected (Kumar 2012) because of their relative importance to the topic. Interviews were conducted in respondents' homes and offices, and in restaurants; they lasted 20-90 minutes each and were recorded. All recordings were transcribed. Ten informal conversations took place with various officials. Interview transcripts and documents were analysed thematically, implying 'a form of pattern recognition within the data, where emerging themes become the categories for analysis' (Fereday and Muir-Cochrane 2006: 4).

The official data used in this study includes the number of hunted animals through sport hunting and income generated between 2001-2016 (Lake Mburo) and 2006-2016 (Kabwoya), poaching rates, and the livelihoods projects financed using hunting income. However, these data may not be free from errors and are not readily available to the public. We, for example, received three different sets of data on hunted animals and hunting income around Lake Mburo. One set was from the hunting company, another from the government and yet another from the hunting evaluation report. It is possible that the differences in these statistics illustrate untrustworthiness of the data (across the different sources), especially where there is no clear separation of power (in terms of data management) between the implementing agency and the supervising agency. In fact, the data presented in the two evaluation reports (e.g., UWA 2002; Muhimbura and Namara 2009) was from the hunting company and the government. Because the figures varied between the different sources in some years, we used the averages of the three sources. It is important to note that the issue of unreliability of the sport hunting data is also well documented in other sources (e.g., Booth 2017). We corroborate this data by presenting quotes (coded to anonymise respondents) from interviews as evidence of respondents' perceptions of the policy impacts, while recognising that this does not resolve the inherent unreliability of the data available for the analysis. We critically reflect on the lack of quality of these data in the discussion section.

The trustworthiness (cf. Decrop 2004) of this research approach was established through the intense engagement of the first author with the two cases. Credibility was enhanced by systematic and transparent data analysis with tangible products (transcripts, codebook, coded transcripts); and joint analysis of the various data sources (interviews and documents) provided validation by triangulation. Finally, the second and third author acted as 'auditors' reviewing analytical procedures and 'adherence to sound research practices' (Decrop 2004: 161).

\section{ANALYSIS OF THE SPORT HUNTING IMPLEMENTATION}

\section{Lake Mburo National Park}

The Lake Mburo sport hunting and its benefits, including direct income, social services and funded development projects, only had a limited impact in terms of improving local residents' attitudes towards wildlife and incidences of poaching. Wildlife is still viewed by the local residents as a nuisance (they destroy crops and compete with livestock for grazing space) even when benefit-sharing rules were adjusted in their favour.

\section{Implementation of sport hunting}

The Uganda Wildlife Authority (UWA - responsible for managing wildlife in Uganda, hereafter the government), implemented sport hunting around Lake Mburo by involving the local governments (both the district and sub-county, hereafter local government) responsible for enforcing government programmes, including wildlife management. The government also engaged the Community Protected Areas 
Table 2

Estimated number of hunted animals through sport hunting per species around Lake Mburo between 2001 and 2016

\begin{tabular}{|c|c|c|c|c|c|c|c|c|c|c|c|c|c|c|c|c|c|}
\hline \multirow[b]{2}{*}{ Species } & \multicolumn{16}{|c|}{ Number of animals hunted per species around Lake Mburo through 2001-2016 (from different sources) } & \multirow{2}{*}{$\begin{array}{l}\text { Total hunted } \\
\text { animals }\end{array}$} \\
\hline & 2001 & 2002 & 2003 & 2004 & 2005 & 2006 & 2007 & 2008 & 2009 & 2010 & 2011 & 2012 & 2013 & 2014 & 2015 & 2016 & \\
\hline Baboon & 0 & 0 & 0 & 0 & 0 & 0 & 0 & 0 & 0 & 0 & 3 & 3 & 5 & 2 & 2 & 0 & 15 \\
\hline Buffalo & 10 & 12 & 13 & 10 & 16 & 16 & 18 & 10 & 11 & 18 & 15 & 13 & 12 & 17 & 14 & 25 & 230 \\
\hline Bushbuck & 9 & 8 & 15 & 8 & 9 & 11 & 13 & 7 & 5 & 13 & 8 & 12 & 7 & 9 & 13 & 15 & 162 \\
\hline Warthog & 1 & 0 & 2 & 0 & 9 & 12 & 16 & 6 & 7 & 15 & 14 & 19 & 18 & 15 & 16 & 15 & 165 \\
\hline Duiker & 1 & 4 & 1 & 3 & 3 & 2 & 7 & 0 & 2 & 5 & 5 & 5 & 1 & 4 & 4 & 6 & 53 \\
\hline Eland & 7 & 5 & 5 & 3 & 4 & 4 & 4 & 3 & 4 & 4 & 3 & 6 & 7 & 6 & 6 & 11 & 82 \\
\hline Hippo & 3 & 2 & 2 & 1 & 4 & 4 & 2 & 2 & 2 & 4 & 5 & 3 & 2 & 1 & 1 & 1 & 39 \\
\hline Impala & 20 & 15 & 20 & 21 & 26 & 30 & 46 & 49 & 15 & 38 & 34 & 34 & 25 & 28 & 36 & 43 & 450 \\
\hline Oribi & 0 & 0 & 0 & 0 & 6 & 4 & 6 & 3 & 1 & 0 & 0 & 0 & 0 & 0 & 0 & 0 & 20 \\
\hline Reed buck & 0 & 0 & 0 & 0 & 7 & 6 & 8 & 3 & 0 & 0 & 8 & 2 & 2 & 4 & 4 & 4 & 48 \\
\hline Topis & 0 & 0 & 0 & 0 & 7 & 9 & 6 & 2 & 2 & 9 & 6 & 5 & 6 & 9 & 11 & 13 & 85 \\
\hline Water buck & 2 & 11 & 9 & 5 & 14 & 15 & 13 & 16 & 2 & 9 & 13 & 15 & 12 & 11 & 13 & 17 & 177 \\
\hline Zebra & 0 & 0 & 0 & 0 & 19 & 31 & 34 & 26 & 9 & 14 & 16 & 28 & 19 & 18 & 16 & 42 & 272 \\
\hline Leopard & 0 & 0 & 0 & 0 & 0 & 0 & 2 & 0 & 1 & 0 & 1 & 0 & 1 & 0 & 1 & 0 & 6 \\
\hline Bush pig & 0 & 1 & 0 & 1 & 0 & 0 & 2 & 2 & 0 & 0 & 2 & 1 & 0 & 2 & 1 & 0 & 12 \\
\hline Hyena & 0 & 0 & 0 & 0 & 0 & 0 & 0 & 0 & 0 & 0 & 0 & 0 & 0 & 0 & 1 & 0 & 1 \\
\hline Sitatunga & 0 & 0 & 0 & 0 & 0 & 0 & 0 & 0 & 0 & 0 & 0 & 0 & 0 & 0 & 0 & 2 & 2 \\
\hline Total & 53 & 58 & 67 & 52 & 124 & 144 & 177 & 129 & 61 & 129 & 133 & 146 & 117 & 126 & 139 & 194 & 1,891 \\
\hline
\end{tabular}

Sources: Muhimbura and Namara 2009; UWA 2017; GTL undated

Institutions (hereafter institutions), formed by the government in 1997 to harmonise community-protected area interactions in Uganda, Associations (registered community-based organisations to manage hunting benefits), and the landowners (individuals who own land around Lake Mburo where hunting is conducted).

The policy guiding sport hunting allows $2 \%$ of adult male animals to be killed (R1) - based on census results per species (R25, R46), but the data on wildlife numbers is unreliable. Based on three data sets on the numbers of hunted animals, we estimate that 1,819 animals were hunted between 20012016. The most hunted species include impala and zebra while the least hunted are sitatunga and hyena (Table 2). This hunting is mainly regulated by the government through its rangers, who escort sport hunters and record the details of the hunted animals, including the Global Positioning System (GPS) locations of where an animal is killed (R1, R2, R46). The recording is then used to identify the landowner who later receives direct revenue based on the specified revenuesharing rules (R2; see Table 3). Furthermore, the government provides strategic plan and monitoring and research plan for regular monitoring (although this has not always happened) of the operations of Game Trails Uganda Limited (hereafter the hunting company) to avoid affecting the species populations, abundance and distribution that can be caused by killing more than the specified annual quota per animal species (R1, R46). Similarly, the 2015 professional hunting agreement (signed by all actors) stipulates that the hunting company can only hunt on private land outside Lake Mburo. This involves killing of healthy mature male animals, for their treasured trophies. Any form of non-compliance by the company or its clients is supposed to be penalised, which could even mean revoking the company's hunting license (UWA 2015). So far, the company's hunting license has not been revoked in 16 years. Even so, there is need for regular monitoring and public reporting to ensure that the $2 \%$ rule is not violated, and to avoid threatening the very species it is now supposed to protect, as more sport hunters are bound to look for healthy male animals that could be leaders of herds.

\section{Benefit sharing arrangement}

One of the goals of the sport hunting policy was to provide incentives for local residents to protect wildlife. A government official (R46) confirmed "it was to demonstrate the economic value of wildlife to the community." Since its implementation, almost USD 1M was generated from sport hunting (Table 4). The income was shared according to the hunting agreement's benefit-sharing rules. These rules specify the beneficiaries and amount of monetary benefit they are entitled to (Table 3 ).

The local residents received the benefits, either as an Association or a landowner. The residents received different benefits from sport hunting, including income, meat, and employment (R5). Although $80 \%$ of the generated benefits went to the local residents (Association and landowner) (Figure 2), as time went by, the majority of the respondents became discontented with the benefits, claiming that more revenue should be returned as household income. As a landowner (R4) complained: "we are receiving peanuts," and a tourism association representative (R24) observed, "the money only benefits a few individuals who are influential." Dissatisfaction with the revenue sharing fuelled disputes over the benefits between the big landowners and the small or nonlandowners, who claimed that the big landowners benefitted disproportionately and maintained that, as a rule, they only benefitted through public goods financed by the association. Moreover, this conflict about the benefits also manifested in an 
346 / Ochieng et al.

Table 3

The revenue-sharing percentages for various actors

\begin{tabular}{|c|c|c|c|c|}
\hline \multirow[b]{2}{*}{ Actor } & \multicolumn{4}{|c|}{$\%$ revenue-sharing } \\
\hline & 2001 & 2003 & 2008 & 2012 \\
\hline \multicolumn{5}{|l|}{ Lake Mburo National Park } \\
\hline Associations & 65 & 65 & 45 & 40 \\
\hline Government & 25 & 15 & 15 & 10 \\
\hline Landowner & 0 & 10 & 30 & 50 \\
\hline Institution & 5 & 5 & 5 & 0 \\
\hline Local Government (sub-county) & 5 & 5 & 5 & 0 \\
\hline \multicolumn{5}{|c|}{ Kabwoya and Kaiso-Tonya Game Management Area } \\
\hline Government & & & 50 & \\
\hline Association & & & 20 & \\
\hline District local government & & & 15 & \\
\hline Kabwoya parish (sub-county) & & & 7.5 & \\
\hline Buseruka parish (sub-county) & & & 7.5 & \\
\hline
\end{tabular}

Source: Ochieng et al. 2018

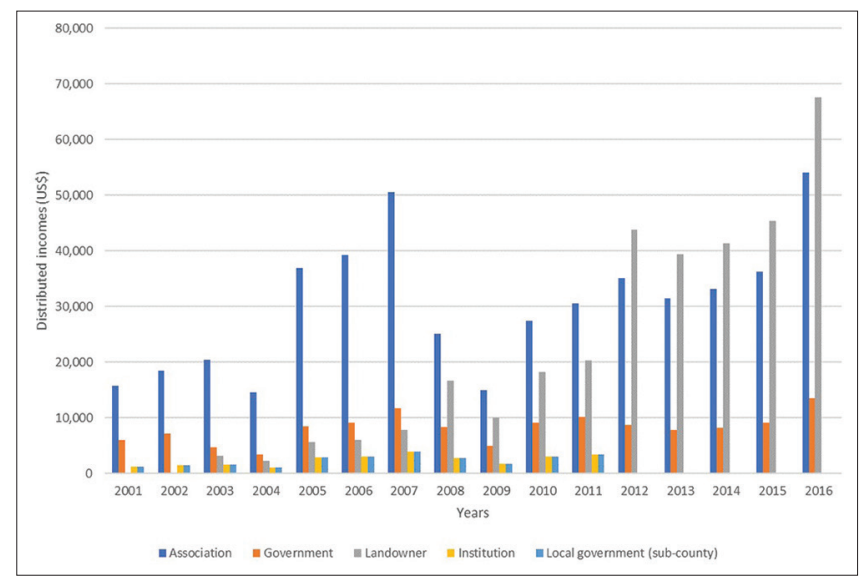

Figure 2

Distributed income in USD around Lake Mburo between 2001-2016 Source: UWA, 2017

attempted but failed 'elite capture' of the hunting benefits by larger landowners who are originally from the region but are currently mainly living in the capital city Kampala.

Although the government also receives a share of the hunting income, which is supposed to be reinvested in monitoring and conservation, there is no paper evidence of how much of the income from sport hunting or traditional tourism is being used for conservation. Only one government representative stated that this income was partly used for monitoring illegal activities around Lake Mburo: "We use it to carry out patrols and monitoring [...] we also finance community wildlife education" (R46). Moreover, only $10 \%$ of the income around Lake Mburo currently directly flows back to the national government (Table 3).

\section{Impact on local wellbeing}

As individuals, out of approximately 2,591 landowners around Lake Mburo, only 461 landowners allegedly received direct income (R2) to cater for their household needs (R4, R6). These are landowners beyond the $5 \mathrm{~km}$ radius from the park boundary where hunting is prohibited - implying landowners closer to the park boundaries cannot receive direct income.
Even so, hunting is randomly done: having an animal killed on one's land and receiving direct income is based on chance. One landowner (R2) mentioned, "I paid school fees for my children, fenced my banana plantation, [...] and employ five scouts on my land to monitor encroachment $[\ldots]$ whenever they see anybody hunting on my land they call me." The scouts are paid an incentive of USD 8 only if they report and the poacher/ encroacher is arrested by the government or the company rangers. This amount is based on an informal agreement between the scout(s) and the landowner(s). Similarly, some 13 workers were employed by the company at its camp - most of them former poachers - earning between USD 33 and USD 167 per month (R1).

Generally, the association used its income (about USD 53,000 ) to finance different community projects between 2010 and 2015, e.g., school dormitory blocks and classroom blocks, health centres, roads, churches and mosques (R2, R4, R46, Table 5). The infrastructural transformation in Rurambiira parish (a parish is the lowest administrative unit in Uganda) in Nyakashashara sub-county, formerly a remote village, as well as in other sub-counties is a very tangible development funded by the sport hunting income. The majority of the local resident landowners in Rurambiira parish have been able to construct semi-permanent houses within the Kashenshero trading centre and now run small-scale retail businesses. Furthermore, a murram road (murram road=gravel road) was opened to link Rurambiira trading centre to Kagetti trading centre on the main Masaka-Mbarara highway, which helped to ease travelling and boosted trade between the villages and nearby towns of Mbarara and Lyantonde.

Although the majority of stakeholders are of the opinion that sport hunting improved the wellbeing of the residents, a few are disappointed by the quality of the facilities. The hunting company representative (R1) lamented 'now the maternity ward is cracked.' This is explained by the unprofessional manner in which the facilities are constructed - without proper supervision by the (local) governments - resulting in low-quality facilities. Hence, the majority of interviewed residents are of the opinion 


\begin{tabular}{|c|c|c|c|c|c|c|c|c|c|c|c|c|c|c|c|c|}
\hline 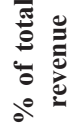 & & & & & & & & & & & & & & & & 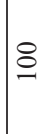 \\
\hline 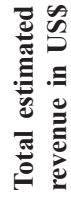 & & & & & & 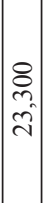 & 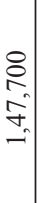 & & 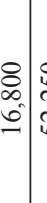 & & & & & & & 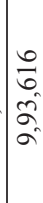 \\
\hline ปิ & 0 & 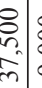 & 8 & & 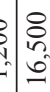 & 8 & $\begin{array}{l}0 \\
n \\
n \\
n\end{array}$ & & : & $\frac{8}{a}$ & \begin{tabular}{l}
$:$ \\
$:$ \\
\hdashline \\
\hdashline
\end{tabular} & $\begin{array}{c}8 \\
8 \\
\\
2\end{array}$ & & 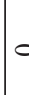 & & $\frac{8}{8}$ \\
\hline & & \begin{tabular}{c}
0 \\
$\vdots$ \\
\hdashline
\end{tabular} & 8 & $b_{\infty}^{\circ}$ & $0 \%$ & 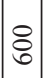 & 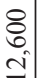 & 0 & : & 8 & $\begin{array}{l}0 \\
\vdots \\
0 \\
\end{array}$ & 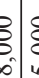 & $\varepsilon$ & 8 & & $\frac{9}{\frac{9}{1}}$ \\
\hline & f & 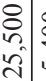 & $\begin{array}{c}8 \\
⿱ 亠 䒑 \\
n \\
n\end{array}$ & 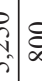 & $b_{0}^{\circ}$ & : & $\begin{array}{c}8 \\
\vdots \\
\infty \\
\vdots \\
0\end{array}$ & & : & $\begin{array}{l}3 \\
\vdots \\
0 \\
0\end{array}$ & 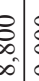 & : & 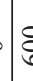 & 10 & & $\begin{array}{l}8 \\
0 \\
0 \\
\text { s. }\end{array}$ \\
\hline ֻ & 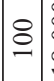 & 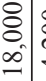 & 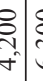 & 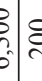 & & 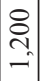 & 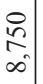 & 0 & 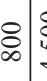 & \begin{tabular}{l}
0 \\
$\vdots$ \\
\hdashline \\
\hdashline
\end{tabular} & 离 & 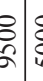 & & $c$ & & 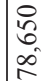 \\
\hline & 8 & & : & 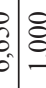 & $=$ & $\begin{array}{l}8 \\
\infty \\
- \\
-1\end{array}$ & $\begin{array}{l}\stackrel{\vdots}{\circ} \\
= \\
=\end{array}$ & & \& & $\begin{array}{c}3 \\
\vdots \\
n \\
n\end{array}$ & & 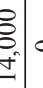 & 8 & lo & & $\begin{array}{l}8 \\
0 \\
0 \\
\infty \\
\infty\end{array}$ \\
\hline & $\stackrel{\gtrless}{\wedge}$ & $\begin{array}{c}0 \\
\swarrow \\
\vdots \\
n\end{array}$ & & $\begin{array}{l}b_{0} \\
f^{2}\end{array}$ & 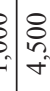 & \begin{tabular}{|}
8 \\
$\vdots$ \\
$\dot{m}$
\end{tabular} & $\begin{array}{l}\stackrel{8}{\circ} \\
=\end{array}$ & 0 & 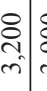 & $\begin{array}{l}8 \\
8 \\
m\end{array}$ & 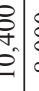 & $\begin{array}{c}8 \\
8 \\
-0^{\circ}\end{array}$ & 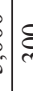 & 10 & & 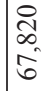 \\
\hline 詃 & 0 & $\begin{array}{l}\stackrel{2}{2} \\
=\end{array}$ & $\begin{array}{c}8 \\
8\end{array}$ & $\stackrel{8}{f}$ & 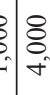 & $\begin{array}{l}8 \\
\vdots \\
i \\
\text {. }\end{array}$ & $\begin{array}{c}8 \\
\stackrel{0}{2} \\
\end{array}$ & 0 & 0 & 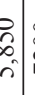 & 8 & 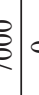 & 18 & lo & & $\left|\begin{array}{l}0 \\
0 \\
0 \\
0 \\
0\end{array}\right|$ \\
\hline & 0 & $\begin{array}{l}0 \\
: \\
\therefore\end{array}$ & 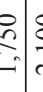 & $\vec{s}$ & 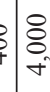 & : & 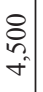 & : & 0 & 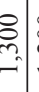 & $\stackrel{8}{8}$ & $\begin{array}{ll}b_{2} \\
f^{2}\end{array}$ & & 10 & & $\left|\begin{array}{l}0 \\
\\
m \\
m\end{array}\right|$ \\
\hline 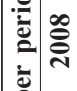 & 0 & $\begin{array}{c}8 \\
0 \\
0 \\
0\end{array}$ & 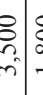 & : & 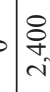 & 总 & 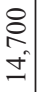 & $\begin{array}{c}8 \\
: \\
\forall \\
\end{array}$ & $\S$ & 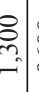 & & 8 & 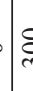 & & & $\begin{array}{l}8 \\
6 \\
i \\
i n\end{array}$ \\
\hline 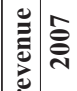 & 0 & : & : & 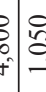 & 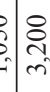 & 总 & 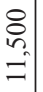 & \& & 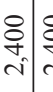 & 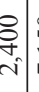 & 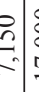 & \begin{tabular}{l}
8 \\
\hdashline \\
\hdashline
\end{tabular} & 8 & 0 & & $\mid \begin{array}{l}0 \\
\vdots \\
i \\
i\end{array}$ \\
\hline & 0 & 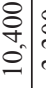 & $\begin{array}{c}\overbrace{m} \\
\S\end{array}$ & : & 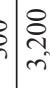 & $\mid \begin{array}{l}0 \\
\dot{a} \\
i \\
i\end{array}$ & 量 & ఫ్ర & 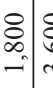 & 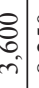 & $\begin{array}{cc}0 \\
\vdots \\
\infty \\
\infty\end{array}$ & $\begin{array}{l}8 \\
n^{2} \\
n\end{array}$ & 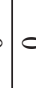 & $c$ & & $\left|\begin{array}{l}0 \\
0 \\
7 \\
8 \\
8\end{array}\right|$ \\
\hline సิ & 0 & 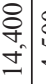 & 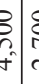 & s. & R. & $\left|\begin{array}{l}8 \\
\vdots \\
i \\
i\end{array}\right|$ & 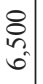 & 亮 & 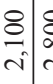 & $\begin{array}{c}8 \\
\infty \\
i \\
i\end{array}$ & & م. & 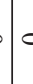 & 10 & & 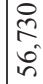 \\
\hline ডั̀ & 0 & O. & 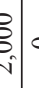 & \& & : & : & 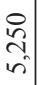 & 0 & 0 & 0 & 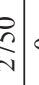 & & 8 & 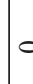 & & $\begin{array}{l}q \\
\text { g } \\
\text { in }\end{array}$ \\
\hline సิํํ & 0 & $\begin{array}{l}\vdots \\
= \\
=\end{array}$ & $n$ & $5-1-$ & 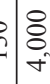 & 总 & $\begin{array}{c}8 \\
\vdots \\
\text { in }\end{array}$ & 0 & . & & $\begin{array}{l}0 \\
\sigma \\
\sigma \\
\sigma\end{array}$ & 0 & & 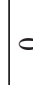 & & $\begin{array}{l}\stackrel{m}{m} \\
\stackrel{m}{m}\end{array}$ \\
\hline ิิ & 0 & $\begin{array}{l}\infty \\
0 \\
0\end{array}$ & $\mathbb{S}_{i}$ & $0 \curvearrowright$ & : & : & $\begin{array}{c}\stackrel{8}{n} \\
m \\
m\end{array}$ & 。 & 0 & & $\begin{array}{l}0 \\
0 \\
0 \\
0\end{array}$ & & & & & $\mid \begin{array}{l}\stackrel{P}{f} \\
\dot{d} \\
\stackrel{\sim}{\sim}\end{array}$ \\
\hline ڤ్తి & 0 & హ. & הi & $\stackrel{0}{0}$ & 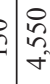 & $\begin{array}{l}8 \\
0 \\
-\infty\end{array}$ & $\begin{array}{c}8 \\
8 \\
\text { nn }\end{array}$ & 0 & 00 & & $\stackrel{8}{=}$ & & & & & 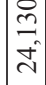 \\
\hline के & & & & & & & & & $\approx F$ & & & & & & & \\
\hline
\end{tabular}

that all the income should be distributed among themselves to meet their household needs (R13, R14, R16).

\section{Impact in terms of reducing poaching}

Government officials (R23, R25) confirmed that the government introduced sport hunting to reduce poaching. However, the policy's effectiveness in reducing poaching has varied significantly over time. The numbers of arrested poachers remained low in the early years of sport hunting (i.e., between 2001 and 2004) (Figure 3), because the local residents reduced poaching and also reported outsiders (from the nearby communities) who had access to the area or connections with people in the area (Muhimbura and Namara 2009), especially after receiving awards (R1, R2). A resident (R9) confirmed, "I blow the whistle on every poacher taking away the animals." There was also shared patrolling by the government, hunting company and the association (UWA 2015).

As Figure 3 illustrates, in subsequent years, poaching picked up with fluctuations in poaching seizure data, consistent across the years with two peaks in 2006/2007 and 2014/2015. These figures are high because some poachers were arrested several times a year (R1, R2). For example, about 388 poachers were arrested in $2014 / 2015$. Overall, substantially higher numbers were recorded in the years after 2006/2007, more than, for instance, in 2002-2004. This possibly indicates that residents either practised retaliatory killing or perpetuated poaching for either subsistence or small-scale commercial purposes, even while they were receiving sport hunting benefits (R6, R7). They were driven by the local demand for low-priced alternative sources of animal protein (Kisame et al. 2017). For instance, the local residents, living within a $5 \mathrm{~km}$ radius from Lake Mburo, allegedly connive with poachers to kill game and sell the meat to local restaurants (R2, R6, R7). One local resident (R10) confirmed, "there is a local restaurant in Lyantonde town where I eat [...] I realised I was not eating beef but zebra meat." During fieldwork the meat of an entire impala was being sold for between USD 111 and USD 195, and zebra for USD 69 to USD 139 (R1, R10). As such, the high poaching seizure numbers between 2006-2007 and 20132016 are probably still too low, and more animals were being killed off-the-record. So these data may not be very reliable,

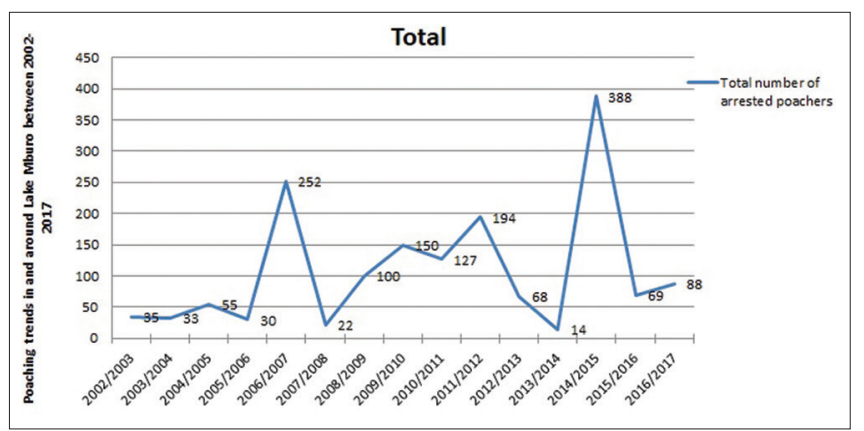

Figure 3

Estimated poaching trends in and around Lake Mburo between 2002-2016

Source: UWA, 2015; 2017 
Table 5

Projects financed using hunting income around Lake Mburo between 2001-2015

\begin{tabular}{|c|c|c|c|}
\hline \multirow[b]{2}{*}{ Sub-county } & \multicolumn{2}{|c|}{ Project and period } & \multirow{2}{*}{$\begin{array}{c}\text { Amount } \\
\text { (US\$) }\end{array}$} \\
\hline & 2001-20071 & 2010-20152 & \\
\hline \multirow[t]{5}{*}{ Nyakashashara } & $\begin{array}{l}\text { Kashenshero Primary School - dormitory block, } \\
\text { latrines, staff kitchen, water tank, fencing, } \\
\text { mattresses, beds, boarding contribution }\end{array}$ & $\begin{array}{l}\text { Construction of Rurambiira Church of Uganda (Anglican } \\
\text { church) }\end{array}$ & 11,765 \\
\hline & Two water dams & Construction of Rurambiira Church house (Priest's residence) & 2,941 \\
\hline & $\begin{array}{l}\text { Nyanga Primary School contribution, teachers' } \\
\text { salaries, teachers' lunch }\end{array}$ & $\begin{array}{l}\text { Construction of two classroom blocks at Birunduma Primary } \\
\text { school }\end{array}$ & 4,706 \\
\hline & $\begin{array}{l}\text { Administrative costs - meetings, stationery, } \\
\text { communication, office rent, writing Constitution, } \\
\text { compound maintenance, transport }\end{array}$ & $\begin{array}{l}\text { Construction of classroom blocks at Nyakahiita Primary } \\
\text { School }\end{array}$ & 3,235 \\
\hline & Cattle vaccination against anthrax & Opening of a (new) $3 \mathrm{~km}$ Karunyiga-Rwitsura feeder road & 4,706 \\
\hline \multirow[t]{11}{*}{ Kanyaryeru } & $\begin{array}{l}\text { Health centre with staff house, kitchen, water } \\
\text { tank and } 2 \text { latrines }\end{array}$ & \multirow[t]{7}{*}{ Construction of Rwamuranda boarding Primary School } & \multirow[t]{7}{*}{2,544} \\
\hline & Karengo Primary School classroom block & & \\
\hline & Girls' dormitory at Sanga Senior School & & \\
\hline & Cattle vaccination against anthrax & & \\
\hline & Water dam in Akayanja & & \\
\hline & $\begin{array}{l}\text { Graded Sanga to Kibuza road (approximately } \\
21 \mathrm{~km} \text { ) }\end{array}$ & & \\
\hline & Ntura Primary School - two classroom blocks & & \\
\hline & Kigarama Primary School - two classroom blocks & Contribution to renovate Kibega Primary School & 1,309 \\
\hline & Rwemikunyu primary school & Construction of Toilets at Akayanja Primary School & 1,529 \\
\hline & Facilitated annual community education meetings & Staff office & 2,294 \\
\hline & $\begin{array}{l}\text { Administrative expenses - opening of bank } \\
\text { account, office opening and rent, meetings and } \\
\text { allowances, welfare, intelligence information, } \\
\text { coordination allowances }\end{array}$ & Classroom block & 3,824 \\
\hline \multirow[t]{9}{*}{ Sanga I and II } & & $\begin{array}{l}\text { Construction of two classroom blocks at Rwemikunyu } \\
\text { Primary School }\end{array}$ & 2,647 \\
\hline & & Contribution to Rwabarata Health Centre & 1,471 \\
\hline & & Contribution to Kakagate Primary School & 735 \\
\hline & & Contribution to Sanga Church of Uganda (Anglican church) & 882 \\
\hline & & Contribution to Sanga parents Primary School & 1,471 \\
\hline & & Contribution to Sanga Muslim Primary School & 735 \\
\hline & & Contribution for acaricide distribution & 1,471 \\
\hline & & $\begin{array}{l}\text { Contribution to the construction of four classroom blocks at } \\
\text { Kikatsi Primary School }\end{array}$ & 4,285 \\
\hline & & Contribution to the renovation Bisheshe Primary School & 706 \\
\hline Total expenditure & & & 53,256 \\
\hline
\end{tabular}

${ }^{1}$ Muhimbura and Namara, 2009; ${ }^{2}$ Association records, 2015

especially because we received two sets of seizure data and averaged them (UWA 2015; 2017).

Although the government and the company have tried to recruit and employ scouts, and arrested some poachers, they have not been very successful. Many poachers do not have permanent addresses, making it hard to write anti-poaching agreements and to warn them (R2). Whilst poaching (and particularly retaliatory killing) is perpetuated, as revenge for crops destroyed on private land (R10), the government lacks a strong and independent legal framework to deal with culprits. Perpetrators are often released by the police after paying a bribe of about USD 46 (R2, R36), after which they usually return to poaching.

\section{Local residents' views of wildlife and its benefits}

The sport hunting policy only partially changed community attitudes towards wildlife. Our results show that although the residents' 'ultimate' aim is to benefit from wildlife, their mostly negative attitudes towards wildlife have not significantly changed. They also have mixed perceptions of the benefits from wildlife.

Internal (UWA 2002) and external (Muhimbura and Namara 2009) evaluations also revealed that although sport hunting generated benefits, it only partially improved residents' attitudes towards wildlife (R19, R23, R46). The majority of landowners are critical of the current hunting benefits: it does not compensate for wildlife damages, and not everyone benefits directly (R4, R24). Only the big landowners benefit directly, at the expense of the small or non-landowners (R10).

Moreover, landowners are changing the Lake Mburo landscape by diversifying land uses to include cultivation and rearing exotic livestock, such as cows and goats. A government representative (R46) confirmed that "change in land use is a challenge," as it can destroy wildlife habitat, and the exotic 
livestock is incompatible with wildlife and could result in a greater number of human-wildlife conflicts. This can have a negative impact on policy effectiveness, as the benefits are thought to be lower than the possible extra income from land-use change. Most of the landowners claimed that the government was the main beneficiary from (hunting) tourism, although they were the ones who were expected to protect the animals on their land (R4, R5). This demonstrates that the policy is failing to achieve its intended goal of changing local residents' attitudes towards wildlife through the sharing of benefits. It is, thus, a manifestation of the fact that most conservation policies fail to deliver satisfactory results to all stakeholders, especially where stakeholder interests are varied-with some conflicting with conservation goals.

Although the association uses hunting income to finance so-called 'social goods' (Table 5), the majority of respondents are of the opinion that these 'goods' should be provided by the central government (R13, R14, R16). One community member (R4) noted, "they are making the government ignore its responsibilities," as private actors provide public goods and services; a role traditionally played by the government. Thus, a majority of the landowners are, therefore, of the opinion that the 2012 benefit-sharing rules should be adjusted so that at least $90 \%$ of the sport hunting revenue is allocated to individual landowners (R2). Furthermore, the landowners demand for the annual hunting quota to be increased to generate more income (R7). This shows that the conflict over the benefits remains unsettled. Although allocating more benefits to individual landowners may improve household incomes, it could perpetuate local inequality as bigger landowners would continue to receive a bigger share than the small and non-landowners.

\section{Kabwoya and Kaiso-Tonya Game Management Area}

In comparison to Lake Mburo, sport hunting benefits in Kabwoya created a stronger, albeit temporary, interest of local residents in conservation. The local residents, however, continued poaching for subsistence and small-scale commercial purposes.

\section{Implementation of sport hunting}

In Kabwoya, sport hunting started when the government and Lake Albert Safaris (hereafter the hunting company) collaborated with the Hoima District Local Government and the local communities represented by Kabwoya and Kaiso-Tonya Community Wildlife Association (hereafter the Association). Following an application by the hunting company in 2002 for a concession to use Kabwoya for (sport hunting) tourism (R46), the government decided to increase the number of game in the area by translocating animals from other protected areas (R45). The government, local governments and the company signed a 20-year lease agreement in 2005, where the company was to construct a tourist lodge and eventually provide residents (especially former poachers) with employment opportunities. In 2006 the government introduced hunting in a formal government protected area covering 87 sq. $\mathrm{km}$ and in 2008 expanded it to Kaiso-Tonya Community Wildlife Area, covering 107 sq. km, as opposed to Lake Mburo, where hunting only takes place on private land outside of the protected area. The rules regarding hunting here are the same as in Lake Mburo except that $4 \%$ adult male animals of certain species are killed based on census results per species even when the rule on paper stipulate $2 \%$. One government official (R23) mentioned, "Kabwoya had many Uganda kobs and warthogs of which if the company was to remove $4 \%$, the conditions would still be sufficient for sport hunting." The other hunted species are the same as in Lake Mburo. A total of 452 animals were hunted between 2008 and 2016 (Table 6).

\section{The benefit-sharing arrangement}

Apart from generating income for the government, the association and the local governments also receive direct

Table 6

Number of hunted animals through sport hunting in Kabwoya between 2008-2016

\begin{tabular}{|c|c|c|c|c|c|c|c|c|c|c|}
\hline \multirow[b]{2}{*}{ Species } & \multicolumn{9}{|c|}{ Period } & \multirow{2}{*}{$\begin{array}{c}\text { Total } \\
\text { hunted }\end{array}$} \\
\hline & 2008 & 2009 & 2010 & 2011 & 2012 & 2013 & 2014 & 2015 & 2016 & \\
\hline Baboon & 5 & 7 & 4 & 0 & 13 & 3 & 6 & 2 & 5 & 45 \\
\hline Buffalo & 1 & 2 & 3 & 3 & 2 & 0 & 1 & 3 & 3 & 18 \\
\hline Bushbuck & 10 & 11 & 11 & 9 & 11 & & 9 & 11 & 14 & 86 \\
\hline Bushpig & 0 & 0 & 0 & 0 & 0 & 0 & 0 & & 0 & 0 \\
\hline Bush Duiker & 3 & 12 & 7 & 3 & 6 & 6 & 5 & 4 & 10 & 56 \\
\hline Oribi & 6 & 10 & 6 & 2 & 5 & 6 & 5 & 3 & 6 & 49 \\
\hline Warthog & 2 & 10 & 10 & 6 & 7 & 3 & 7 & 6 & 10 & 61 \\
\hline Waterbuck & & & & & & 9 & & & 2 & 11 \\
\hline Ugamda kob & 18 & 17 & 10 & 12 & 17 & 9 & 10 & 10 & 16 & 119 \\
\hline Vervet Monkey & & & & & & & 0 & & & 0 \\
\hline Hippopotamus & & & & & & 0 & & & 0 & 0 \\
\hline Black and White Colobus Monkey & & & & & & 3 & & 2 & & 5 \\
\hline Leopard & & & & & & 0 & & & 0 & 0 \\
\hline Hartebeest & & & & & & & & 1 & 1 & 2 \\
\hline Total & 45 & 69 & 51 & 35 & 61 & 39 & 43 & 42 & 67 & 452 \\
\hline
\end{tabular}

Source: UWA 2017 
benefits. An Association representative (R28) confirmed, "there was no other source of income for the community." Thus, a total of USD 371,573 hunting income was generated between 2006 and 2016 (Figure 4) and shared according to the hunting agreement's benefit-sharing rules (Table 3 ). However, the profit the hunting company makes from sport hunting remains unknown business information to the public.

However, the government fully retained the hunting income in the first four years (i.e., 2006-2009) because there was no functional revenue-sharing agreement (R25) and hunting was only conducted in the formal government protected area (R45). The communities started receiving income in 2010 following the expansion of hunting to the community-owned land (R37, R41). Since then, the government monitors hunting and the distribution of benefits by the company to the other stakeholders. Association representative (R34) confirmed, "the government ensures that the money is shared." Similarly, the 2013 revenue-sharing agreement in Kabwoya stipulates that the government has to offer technical advice to the association about providing 'social goods' with the aim of helping to improve the residents' attitudes towards wildlife.

\section{Impacts on local wellbeing}

The income received by the association was used to finance social and development projects in Kabwoya, Buseruka and Kyangwali sub-counties (Table 7). This followed consultative meetings of the association and the wider community to generate a list of needs for funding (R35). The lists usually vary but include mostly public goods, such as schools and clinics (R25, R29, R31). One association representative (R37) explained, "we supported the construction of teachers' quarters in Tonya and Kabaale public schools." Similarly, the association supported organised groups to

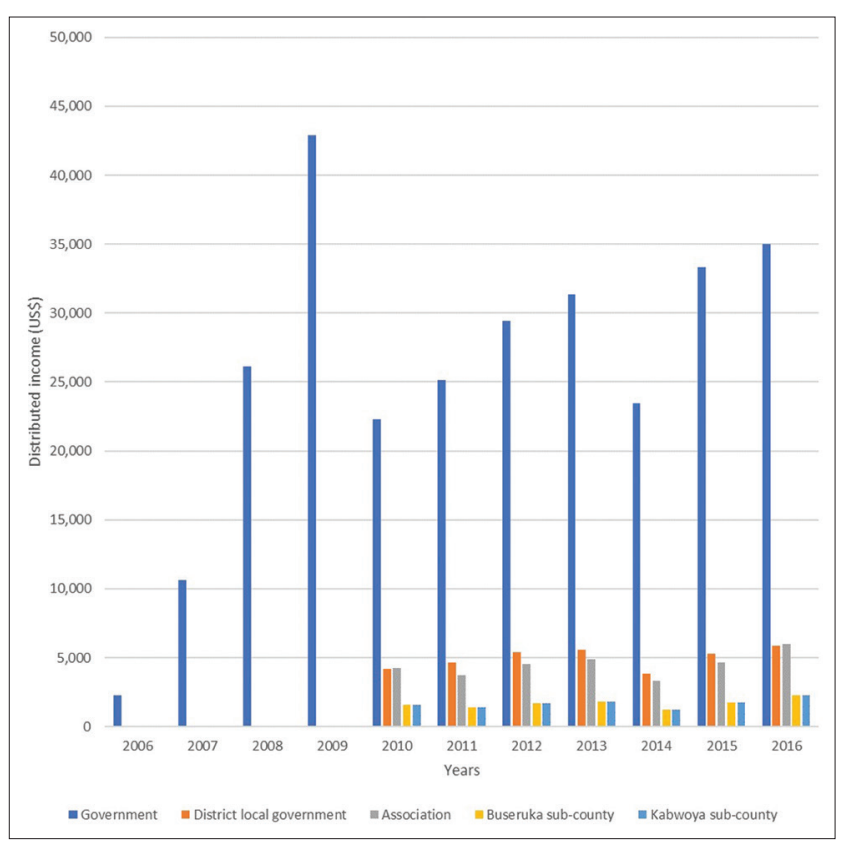

Figure 4

Distributed income in Kabwoya between 2006-2016 in USD Source: $U \boldsymbol{W A}, 2017$ start up pig farming, goat keeping, beekeeping, and tree-planting projects (R32, R35). These projects are intended to improve household income and to eventually reduce (or stop) poaching. It is not clear how the district and the sub-counties used their income. The government claims it used its income to carry out patrols and monitor encroachments in Kabwoya (R41), including sensitising residents to conservation (R46). However, there was no paper evidence for the income from sport hunting being used by the government for conservation. Some interviewees (R41, R36, R46) did state that this income was partly used for monitoring illegal activities, conducting animal censuses, and sensitising and hiring community wildlife scouts. Some residents also alleged that the projects financed with hunting income do not translate into improved household income (R34). Also, the actual amount spent by the association in providing the 'social goods' largely remained unclear (except for where respondents were able to estimate the activities/project costs (Table 7)), reflecting inconsistency in record keeping, a lack of transparency and accountability. Some residents even stopped working as wildlife scouts and resorted to poaching (R29). One association representative (R28) confirmed, "one guy was given a job as a community scout but left." Moreover, some individuals who previously hunted for commercial purposes (R38) feel deprived of their source of income.

\section{Impact in terms of reducing poaching}

Similar to the Lake Mburo case, the Kawoya residents had a long history of HWC. A community member (R35) confirmed and elaborated, "poaching was almost being done in the open, there was no conservation." This led to the local extinction of some species, such as the hartebeest in the 1980s, while buffalo and waterbuck were reduced to very low numbers (Plumptre et al. 2009). Following the implementation of sport hunting, some respondents (R37, R41, R44) noted that poaching reduced, as some residents reported illegal activities. Association representative (R28) put it: "people have known that they are part of wildlife [...] they report poaching." Similarly, the government conducts regular patrols to curb illegal activities (R45). Those found guilty are jailed for three months or fined USD 42 (R28). As government representative (R41) explained, "we extended patrols, rangers stay in the bush for about four days." Equally, the association organises regular sensitisations to convince known poachers to surrender and register as 'reformers' (R34), who are later recruited as community wildlife scouts (R25, R35, R45, R46). A community leader (R36) elaborated, "when poachers are sensitised [...] they are more likely to appreciate wildlife and to convince others to abandon poaching."

Although we were unable to access poaching seizure data in Kabwoya, as there are said to be no records of it, the residents appear to have diverse expectations of the reserve, including poaching, pastoralism and charcoal production (R29). An Association representative (R28) confirmed, "poachers get more money than they would working as community wildlife scouts." Poachers usually earn about USD 139 from selling Uganda kob meat (R29) and thus usually opt to pay the 
Table 7

Projects financed using hunting revenue in Kabwoya between 2010-2016

\begin{tabular}{|c|c|c|}
\hline Project funded & Beneficiary & Cost in US\$ \\
\hline $\begin{array}{l}\text { A motor cycle for the association chairperson (Transferable in case } \\
\text { one leaves office) }\end{array}$ & Association & 964.9 \\
\hline Eighteen bags of cement for the construction of staff quarters & Kabale Public School & 158.8 \\
\hline Eighteen bags of cement for the construction of staff quarters & Tonya Primary School & 158.8 \\
\hline Mattresses, curtains, blankets and bed sheets & Kabwoya Health Center & \\
\hline Construction of toilets (first phase) & Association & 956 \\
\hline School materials (text books, pens, pencils, and literature books) & Kyehoro primary school, Hoima district & \\
\hline $\begin{array}{l}\text { Sensitisation meetings, Radio programme and formation of resource } \\
\text { use groups }\end{array}$ & All three sub-counties & 634 \\
\hline $\begin{array}{l}\text { Facilitation of meetings to ensure that Rwembogo becomes a } \\
\text { protected buffer zone along Howha river in the CWA }\end{array}$ & Government & 330.9 \\
\hline $\begin{array}{l}\text { Acquiring one acre of land and construction of association offices in } \\
\text { Howha trading centre }\end{array}$ & Association & 964.9 \\
\hline Construction of Association offices & Association & 5100 \\
\hline Designing association logo, T-shirts and sign post & All three sub-counties & 271.5 \\
\hline Acquiring office furniture (two tables, six chairs and four benches) & All three sub-counties & 99.7 \\
\hline Distributing thirty piglets & $\begin{array}{l}\text { Nyakabingo, Igwanjura, Buhogo women's groups (ten } \\
\text { piglets each) }\end{array}$ & 275.6 \\
\hline Distributing thirty high breed goats & Buhuka parish and women's groups & 1240.4 \\
\hline Distributing ten beehives & Nkondo parish community group & 413.6 \\
\hline Donating seventy iron sheets and ten poles for renovation & Humuro and Kimbugu community primary school & 443.9 \\
\hline Acquiring one digital camera & Association & 1282 \\
\hline Fencing Association land & Association & 403.6 \\
\hline $\begin{array}{l}\text { Office stationary (visitors' book, pens), typing and photocopying } 2015 \\
\text { \& } 2016\end{array}$ & Association & 74 \\
\hline $\begin{array}{l}\text { Allowances and transport for } 11 \text { Association executive members twice } \\
\text { a year }\end{array}$ & Association & 485 \\
\hline
\end{tabular}

USD 42 fine and then return to the village to poach (R28). Although this points to a lack of livelihood diversification in the area to enhance wellbeing, some respondents (R29, R35) blame the persistent poaching on the unfair distribution of meat. One community leader (R36) noted, "they were used to wild meat $[\ldots]$ sport hunting has some restrictions," and an Association representative (R30) complained, "sometimes the meat is given to the staff and clients of the company or the government soldiers." Similarly, when the company decides to share the meat, it only delivers to the nearby villages to keep transportation costs low (R29). This means that faraway villages never receive the meat, thereby provoking poaching.

\section{Local residents' views of wildife and its benefits}

The implementation of sport hunting in Kabwoya has received mixed reactions from the stakeholders. While the residents' mostly negative attitudes towards wildlife generally changed over the years, the residents are still more concerned about household wellbeing than conservation.

Those who are given meat are happier as compared to those who have never received any. A local leader (R40) noted, "we have benefited $[\ldots]$ meat and some money to support our projects."

Although the benefits have been shared with the stakeholders, the association criticises the limited amount of income they received (R29, R34, R37). One association representative (R29) complained, "we don't get enough revenue." Another leader (R39) from the same area is not content with the arrangement: "we are given like one Uganda kob, which is not enough [...] they should give like five animals." Another community member (R33) lamented, "we never receive benefits, including meat" reflecting how benefits remain insufficient to guarantee the local residents' continued support for conservation. Consequently, the local residents only temporarily stopped, and resumed poaching for subsistence and small-scale commercial purposes. Moreover, this local policy arrangement is not only characterised by passive community involvement, but also marred by mistrust and a lack of accountability by those in power (R28, R40). There were corruption allegations especially regarding the sharing of meat (R38, R43), and a lack of transparency in terms of data availability as we were even unable to attain poaching seizure data for this site. The person responsible claimed not to have these records. Although a majority of the residents were very interested in conservation in the beginning, they are gradually becoming unhappy about the inadequate benefits' which only perpetuates poverty as more revenue goes to the government. Moreover, a tourism association representative (R24) view sport hunting as a "deceptive activity' that "leads to reductions in species populations."

\section{DISCUSSION}

The myth that sport hunting can be used as a means to raise conservation funds, especially in sub-Saharan Africa has been and continues to be subject of debate around the world. Although proponents of sport hunting (e.g., Lindsey et al. 
2007; 2013) believe it has potential to raise funds to address conservation-development challenges in Africa, there are fundamental socio-economic, ecological and ethical problems associated with it. Southwick (2015) and Weaver et al. (2016) argue that the rate of return from the hunting industry remains minimal in comparison to other conventional land-use activities such as agriculture or traditional, non-consumptive, tourism. In ecological terms, Loveridge et al. (2006) and El Bizri et al. (2015) further contend that commercialisation of nature (cf. McAfee 1999) threatens species survival, just as poaching. Also, the killing of wild animals in the name of conservation (see Hannis, 2017) remains unacceptable to organisations and individuals promoting animal welfare and rights (VisserenHamakers 2018). As it stands, the continued practice of sport hunting to generate conservation funds and improve local wellbeing will continue to attract criticism. Moreover, there are also claims that continued use of sport hunting income to finance 'social goods' leads to what has been referred to as 'hollowing out the state' (Bell and Hindmoor 2009), as private actors are taking over what are usually considered public responsibilities' a practice common with most neoliberal policies.

Several studies on benefits and benefit-sharing have shown that what constitute benefits is always contested (see Archabald and Naughton-Treves 2001; Schroeder 2007; Ahebwa et al. 2012). Most often, the extent of the effectiveness of such benefit-sharing policies is largely influenced by the local dynamics. Our analysis shows that there are mixed outcomes of the sport hunting policy. At the local level, the residents perceive that benefits are insufficient, and accordingly their attitudes towards wildlife did not fundamentally change. This is contrary to the government's expectation that residents' attitudes towards wildlife would improve after receiving benefits. Whereas the Kabwoya residents initially showed changed attitudes after receiving benefits, the Lake Mburo residents still view wildlife as a nuisance (Ocheing et al. 2018). Overall, the majority of the respondents in the two areas are still more concerned about livelihood security than conservation. For example, at Lake Mburo the Bahima community members traditionally consider wild meat to be inferior meat and are less likely to consider meat as a serious benefit. However, the Kabwoya residents consider wild meat to be an important part of their diet, thus explaining their continued calls for more meat to be shared with them.

Another goal of the sport hunting policy is reducing HWC, especially poaching. Our analysis shows that poaching has not been significantly reduced in the two cases. In Kabwoya, the local residents still hunt for subsistence and or small-scale commercial purposes. Poaching was only temporarily low around Lake Mburo after which it increased, on top of the legal hunting. This is demonstrated by the sharp increases in poaching seizure trends between 2006-2007 and 2013-2016 (Figure 3). Around Lake Mburo, the residents have preserved a historical tradition of pastoralism whereby owning large herds of livestock is considered a great sign of wealth. In such situations, increased wildlife numbers are bound to be considered an inconvenience as they will compete with livestock for grazing space, water and other natural resources.
Overall, two main lessons can be learned from our analysis. Firstly, policy effectiveness is threatened by the lack of coordination among government agencies. Although the government implements sport hunting through the UWA with a view to reduce poaching, the same government distributed exotic livestock (cattle and goats) to residents to promote the 'wealth creation' agenda through the National Agricultural Advisory Services. This new policy not only threatens the sustainability of wildlife but also encourages further land-use changes. Consequently, the government translocated 11 zebras and 68 impalas from around Lake Mburo to the Katonga wildlife reserve in western Uganda (UWA 2017), casting doubts about the future of wildlife on private land around Lake Mburo. Whereas historically, wildlife co-existed with the indigenous long-horned Ankole cattle, the exotic breeds require vegetation to be cleared. Similarly, in Kabwoya, the government declared the entire Lake Albert region an oil reservoir. Although intensive oil exploration is underway-for socio-economic transformation (Republic of Uganda, undated), it potentially breaches the government's objective to protect and conserve Kabwoya's varied ecosystems that provide habitat to flora and fauna (see Wanyama and Kisame 2015). These two examples illustrate that: 1) the impact of Uganda's sport hunting policy is undermined by a lack of policy coherence; and 2) there are serious conservation-development trade-offs in the two areas. The different policies in Lake Mburo and Kabwoya have contradicting goals and requirements, although they are all expected to contribute to transforming Uganda from a predominantly peasant/low income economy to a competitive, upper-middle income economy with an average per capita income of USD 9,500 by 2040 (Republic of Uganda, undated).

Secondly, figures on benefits, hunted animals, poaching, and even census data are in essence political, and not as neutral as one might think. We were not able to obtain all the data on the different (financial) benefits generated, animals hunted through sport hunting and poaching, as this data is typically not systematically collected and recorded. Moreover, the census data attained through monitoring the number of animals per species are also flawed as it is irregularly conducted and poorly recorded. Similar inconsistencies regarding sport hunting data sets were observed in Tanzania (Booth 2017). Elsewhere, acquiring data on illegal hunting, for example in Brazil, is also a challenge (El Bizri et al. 2015). Moreover, non-state actors usually have no insight in the actual (income) figures, except for what is shared with them. Although conservation organisations have demanded (income) audits, these data have not been released, nor publicly discussed. This reflects a lack of accountability and transparency, which are key elements of good governance (Bell and Hindmoor 2009). It is, therefore, possible that some data we received from different sources were provided to paint an image of a well-managed and supervised process - a challenge regularly associated with private-sector involvement in biodiversity conservation (MacDonald 2010). It also shows that the sport hunting policy is not based on accurate, reliable data, casting doubts as to its sustainability. 


\section{CONCLUSIONS}

In this paper, we evaluate and analyse the impacts of sport hunting for three formal policy goals around Lake Mburo and Kabwoya in Uganda, namely to (1) reduce human-wildlife conflicts by (2) positively changing residents' attitudes towards wildlife through (3) the providing of incentives for the local inhabitants (UWA 2001).

Our results show that around Lake Mburo sport hunting is practised on private land. It has somewhat enhanced local wellbeing, but the politics of landownership perpetuate disputes over how benefits are distributed. Sport hunting seems to temporarily and partly help to address humanwildlife conflicts, especially as local residents are hired as wildlife scouts. However, there are no official records on how many scouts were hired and paid over the years. Only the associations and a few (of the big) landowners around Lake Mburo who receive direct income talked about hiring some scouts. Moreover, the association and landowners have used a large bulk of the income from sport hunting for conservationunfriendly development, such as diversified land use with arable farming and livestock breeding, accompanied by the construction of new roads, and (semi-)permanent houses, thus destroying habitats. In Kabwoya, sport hunting was reintroduced in a formal government protected area. Although sport hunting in Kabwoya was later extended to a communityowned wildlife area, most residents only had strong interests in conservation at the start, and remained largely unhappy about the hunting benefits, especially the sharing of meat. The residents accused the government and hunting company of holding back meat and not delivering it to the distant villages. Related, the majority of respondents around Lake Mburo believe that the current hunting benefits do not compensate for losses caused by wildlife, and attempts to distribute benefits to the wider community faced an attempted but failed 'elite capture of benefits' especially by the big landowners who reside in the capital Kampala.

It seems that many conservation policies, although wellintended in their objectives, are often characterised by flawed institutional arrangements for benefit sharing. Several studies on the implementation of conservation policies have revealed elite capture of benefits, and lack of transparency by those in power as the reasons why local perceptions of conservation benefits remain negative (Thompson et al. 2009). Results from our case studies reveal that the local residents are of the opinion that sport hunting benefits remain insufficient to make meaningful livelihood improvements, and that attitudes towards wildlife in the two areas have not improved. This is reflected by the resurgence of poaching in both cases, with the residents either directly poaching or aiding other members from nearby communities to poach with the hope to reduce the number of wildlife. This demonstrates that most implementers of conservation policies not only lack understanding of the local context but also suffer from a fundamental misconception that money changes everything. As such, the underlying assumption of the sport hunting policy — that when local residents receive benefits, they will appreciate wildlife and thus human-wildlife conflicts will be reduced - is highly debatable. This is further illustrated by the fact that the communities around Lake Mburo still perceive wildlife as a nuisance even when they receive benefits. In Kabwoya, discontentment over the way meat and other benefits are shared generally led residents to resume poaching. This supports similar findings in earlier studies on market- and community-based conservation (Nthiga et al. 2015), and has significant consequences for conservation policy more generally.

\section{REFERENCES}

Agrawal, A. and C. Gibson 1999. Enchantment and disenchantment: the role of community in natural resource conservation. World Development 27(4): 629-49.

Ahebwa, W.M., R. Van der Duim, and C.G. Sandbrook 2012. Tourism revenue sharing policy at Bwindi Impenetrable National Park, Uganda: a policy arrangements approach. J Sustain Tour 20(3): 377-94.

Archabald, K. and L. Naughton-Treves 2001. Tourism revenue-sharing around national parks in Western Uganda: early efforts to identify and reward local communities. Environ Conserv. 28(2): 135-49.

Arts, B. and P. Leroy. (eds.) 2006. Institutional dynamics in environmental governance. Dordrecht, The Netherlands: Springer.

AU (Africa Union). 2017. Animal welfare strategy for Africa: integrating the welfare interests of human and animals in Africa. African Union, Inter-African Bureau for Animal Resources, Final Report. Addis Ababa, Ethiopia.

Bekoff, M. (ed). 2013. Ignoring nature no more: the case for compassionate conservation. Chicago, IL: University of Chicago Press.

Bell, S. and A. Hindmoor 2009. Rethinking governance: the centrality of the state in modern society. Cambridge: Cambridge University Press.

Booth, V.R. 2017. Economic assessment of the value of wildlife to the Tanzania hunting industry in 2014. A report commissioned by the US Agency for International Development and the US Fish and Wildlife Service at the request of Tanzania's Ministry of Natural Resources and Tourism.

Boyce, C. 2006. Conducting in-depth interviews: a guide for designing and conducting in-depth interviews for evaluation input. Pathfinder International Tool Series, Monitoring and Evaluation - 2.

Byström, M., P. Einarsson, and G. Nycander 1999. Fair and equitable: sharing the benefits from use of genetic resources and traditional knowledge. Stockholm: Swedish Scientific Council on Biological Diversity.

Carpenter, S. and D. M. Konisky. 2017. The killing of Cecil the Lion as an impetus for policy change. Oryx 53(4): 1-9.

Conover, M.R. (2002). Resolving human-wildlife conflicts: the science of wildlife damage management. Boca Raton, FL: CRC Press.

Crabbé, A. and P. Leroy. 2008. The Handbook of Environmental Policy Evaluation. London: Earthscan,

Decrop, A. 2004. Trustworthiness in qualitative tourism research. In: Qualitative research in tourism: ontologies, epistemologies and methodology (eds. Phillimore, J. and L. Goodson). Pp. 156-196. London: Routledge

Di Minin, E., N. Leader-Williams, and C. J. Bradshaw. 2016. Banning trophy hunting will exacerbate biodiversity loss. Trends in Ecology and Evolution 31(2): 99-102.

El Bizri, H., T. Morcatty, J. Lima, and J. Valsecchi. 2015. The thrill of the chase: uncovering illegal sport hunting in Brazil through YouTube ${ }^{\mathrm{TM}}$ posts. Ecology and Society 20(3): 30.

Fereday, J. and E. Muir-Cochrane. 2006. Demonstrating rigor using thematic analysis: a hybrid approach of inductive and deductive coding and theme development. International Journal of Qualitative Methods 5: 80-92. 
Giddens, A. 1984. The constitution of society: outline of the theory of structuration. Oakland, CA: University of California Press.

GTL (Game Trails Uganda Limited). Undated. Sport hunted animals between 2014-2016 around Lake Mburo National Park. GTL, Archives

Hackel, J.D. 1999. Community conservation and the future of Africa's wildlife. Conservation biology, 13(4), 726-734.

Hajer, M.A. and H. Wagenaar. 2003. Deliberative policy analysis: understanding governance in the network society. Cambridge: Cambridge University Press.

HDLG (Hoima District Local Government). 2015. District Development Plan 2015/2016-2019/2020. Hoima, District, Uganda.

Hannis, M. (2017) Killing nature to save it? ethics, economics and the trophy hunting of black rhinoceros. In: BSU Environmental Humanities Research Centre Public Lecture, 13 December 2017, Bath Spa University, UK.

Hulme, D. and M. Murphree 2001. African wildlife and livelihoods: the promise and performance of community conservation. Oxford: James Currey Ltd.

Kisame, F.E., F. Wanyama, G. Basuta, and A. Rwetsiba. 2017. Ground counts for medium to large mammals in Lake Mburo Conservation Area, Uganda. Uganda Wildlife Authority, Kampala, Uganda

Kumar, R. 2012. Research methodology: a step-by-step guide for beginners. London, UK: Sage Publications.

LaPiere, R.T. 1934. Attitudes vs actions. Social Forces 13(2): 230-237.

Levy, M.A. and O. R. Young. 1994. The effectiveness of international regimes. In: Annual convention of the international studies association. Washington DC. March 29to April 1, 1994.

Lindsey, P.A., C.P. Havemann, R.M. Lines, A.E. Price, T.A. Retief, T. Rhebergen, C. Van der Waal, et al.. 2013. Benefits of wildlife-based land uses on private lands in Namibia and limitations affecting their development. Oryx 47(1): 41-53.

Lindsey, P.A., G.A. Balme, P. J. Funston, P.H. Henschel, and L.T.B. Hunter. 2016. Life after Cecil: channelling global outrage into funding for conservation in Africa. Conservation Letters 9(4): 296-301.

Lindsey, P.A., L.G. Frank, R. Alexander, A. Mathieson, and S.S. Romanch. 2007. Trophy hunting and conservation in Africa: problems and one potential solution. Conservation Biology 21: 880-883.

Loveridge, A.J., J.C. Reynolds, and E. Milner-Gulland. 2006. Does sport hunting benefit conservation? In: Key topics in conservation biology (eds Macdonald, D. and K. Service). Pp. 222-238. Oxford, UK: Blackwell Publishing.

MacDonald, K. I. 2010. The devil is in the (bio) diversity: private sector "engagement" and the restructuring of biodiversity conservation. $A$ radical journal of Geography 42(3): 513-550.

McAfee, K. 1999. Selling nature to save it? Biodiversity and green developmentalism. Environment and planning D. Society and space 17(2): 133-154.

Mitchell, R.B. 2003. Of course international institutions matter: but when and how? In: how institutions change (eds. Breit H., A. Engels, T. Moss, and M. Troja). Pp. 35-52. Wiesbaden: Springer VS.

Moon, K. and D. Blackman. 2014. A guide to understanding social science research for natural scientists. Conservation Biology 28(5): 1167-1177.

Mosse, D. 2005. Cultivating development. An ethnography of aid policy and practice. London, UK: Pluto Press.

Muhimbura, A. and A. Namara. 2009. The pilot sport hunting program in the ranches surrounding lake mburo national park. Project evaluation report, draft 2. Kampala: UWA

Muposhi, V.K., E. Gandiwa, P. Bartels, and S.M. Makuza. 2016. Trophy hunting, conservation, and rural development in Zimbabwe: issues, options, and implications. International Journal of Biodiversity 2016: 16.
Nthiga, R.W., R. Van der Duim, I.J. Visseren-Hamakers, and M. Lamers. 2015. Tourism-conservation enterprises for community livelihoods and biodiversity conservation in Kenya. Development Southern Africa 32(3): 407-423.

NWA (Nshaara Wildlife Association). Undated. Records of projects funded using sport hunting money around Lake Mburo National Park. Unpublished report

Ochieng, A. 2019. Killing nature to save it? An analysis of two sport hunting policy arrangements in Uganda. Ph.D. thesis. Wageningen University, Wageningen, The Netherlands.

Ochieng, A., I.J. Visseren-Hamakers, and R. van der Duim. 2018. The battle over the benefits: analysing two sport hunting policy arrangements in Uganda. Oryx 52(2): 359-368.

Plumptre, A.J., N. Mutungire, H. Mugabe, B., Kirunda, C. Bogezi, R. Kityo, M. Behangana, et al. 2009. Biodiversity surveys of Kabwoya Wildlife Reserve and Kaiso Tonya Community Wildlife Area. Kampala: Wildlife Conservation Society.

Republic of Uganda (Undated). 'Uganda Vision 2040'. Available at: http://npa. $\mathrm{ug} / \mathrm{wp}$ - content/themes/npatheme/documents/vision2040.pdf. Accessed on October 29, 2018.

Schroeder, D. 2007. Benefit sharing: it's time for a definition. Journal of medical ethics 33(4): 205-209.

Scoones, I. 2009. Livelihoods perspectives and rural development. The Journal of Peasant Studies 36(1): 171-196.

Southwick. 2015. The economic contributions of hunting-related tourism in Eastern and Southern Africa. Southwick Associates. For Safari Club International Foundation. November, 2015. http://safariclubfoundation. org/wp-content/uploads/2016/06/Southwick-Associates-2015 FINAL. pdf. Accessed on March 12, 2018

Thompson, D.M., S. Serneels, D. Ole Kaelo, and P. Chenevix Trench. 2009. Maasai Mara-land privatization and wildlife decline: can conservation pay its way? In: Staying Maasai? Livelihoods, conservation and development in East African rangelands (eds. Homewood, K., P. Kristjanson, and P. Chenevix Trench). Pp. 77-114. New York, NY: Springer.

UWA (Uganda Wildlife Authority). 2001. Professional Hunting Agreement in the Former Ankole Ranching Scheme Between Uganda Wildlife Authority. Kampala: Rurambiira Wildlife Association and Game Trails (U) Limited.

UWA (Uganda Wildlife Authority). 2002. The implementation of sport hunting project on the ranches outside Lake Mburo National Park: evaluation report on sport hunting with proposals for change. Kampala: Uganda.

UWA (Uganda Wildlife Authority). 2015. Lake Mburo conservation area general management plan. Kampala: UWA.

UWA (Uganda Wildlife Authority). 2017. The Uganda wildlife Authority general management plan 2017-2018. Kampala: UWA.

Visseren-Hamakers, I.J. 2018. A framework for analyzing and practicing integrative governance: the case of global animal and conservation governance. Environment and Planning C 36(8): 1391-1414.

Wanyama, F. and F.E. Kisame. 2015. Medium - large animal ground survey of Kabwoya Wildlife Reserve and Kaiso-Tonya Community Wildlife Area. Kampala: UWA.

White, S.C. 2008. But what is wellbeing? A framework for analysis in social and development policy and practice. In: Conference on regeneration and wellbeing: research into practice. April 24-25 2008: 1-18,Volume 2425. Bradford, UK: University of Bradford.

Yasuda, A. 2011. The impacts of sport hunting on the livelihoods of local people: a case study of bénoué national park, cameroon. Society and Natural Resources 24(8): 860-869.

Yin, R. (2003). Case study research: design and methods. 3rd edition. Thousand Oaks, CA: Sage Publications. 